\title{
APLIKASI PENGENALAN JENIS SAYUR-SAYURAN BERBASIS ANDROID
}

\author{
Putra Sakti Nasution $^{1}$, Fiqih Ismawan ${ }^{2}$ Heriyati $^{3}$ \\ Program Studi Informatika, Fakultas Teknik dan Ilmu Komputer, Universitas Indraprasta PGRI \\ Jalan Raya Tengah No 80, Kelurahan Gedong, Pasar Rebo, Jakarta Timur \\ Nasutionsputra05@gmail.com ${ }^{1}$,vQ.unindra@gmail.com², erymatematika@gmail.com ${ }^{3}$
}

\begin{abstract}
Abstrak
Penelitian ini bertujuan untuk mempermudah setiap orang untuk mengetahui nama-nama jenis sayuran. Pendekatan Aplikasi ini terhadap masyarakat dengan memberikan informasi lengkap terkait detail sederhana dari nama-nama sayuran tersebut dan juga disediakan kuis untuk melatih para pengguna Aplikasi ini tentang tingkat pengetahuan dari setiap nama-nama sayuran. Metodologi penelitian yang digunakan dalam sistem Aplikasi ini adalah metodologi kualitatif yaitu metode penelitian tentang riset yang bersifat cenderung menggunakan analisis. Untuk memperoleh data-data, penelitian menggunakan teknik pengumpulan data seperti wawancara, observasi, studi dokumentasi, serta melakukan penelitian kepustakaan yang relevan dengan masalah sistem-sistem informasi. Metode Pengembangan Sistem yang digunakan menggunakan metode Android. Software yang digunakan adalah APP IVENTOR. Hasil penelitian ini menghasilkan aplikasi pengenalan Jenis sayur-sayuran, Android, nama-nama sayuran.
\end{abstract}

Kata Kunci: Aplikasi, Sayur-Sayuran, Android

\begin{abstract}
This Research aims to make it easier for everyone to know the names of vegetable types. This application approach to the community by providing complete information related to the simple details of the names of the vegetables and also provided quiz to train the users of this application about the level of knowledge of each vegetable names. The research methodology used in this application system is a qualitative methodology of research methods that are more likely to use analysis. To obtain data, the research uses data collection techniques such as interviews, observations, documentation studies, as well as conducting literature research relevant to information systems issues. System development methods used the Android method. The Software used is THE IVENTOR APP. The results of this study resulted in an introduction to the types of vegetables, Android, the names of vegetables.
\end{abstract}

Keyword: Application, Vegetables, Android

\section{PENDAHULUAN}

Berkembangnya Ilmu Pengetahuan dan Teknologi (IPTEK) pada era globalisasi seperti saat ini, pemanfaatannya sengat cepat dan menghasilkan inovasi - inovasi baru yang harus diimbangi dengan kemampuan beradaptasi terhadap teknologi tersebut. Salah satu dari bidang tersebut adalah teknologi informasi yang berbasis komputer multi media. Pemakaian komputer beserta aplikasinya sekarang sudah merambah keberbagai usia dan tidak hanya pemakaian orang dewasa saja akan tetapi sekarang anak-anak sudah mulai diperkenalkan dengan komputer. Hal ini dikarenakan komputer sangat mendukung dalam berbagai hal, baik dalam hal pembelajaran ataupun alat bantu. Multimedia mempermudah anak-anak dalam belajar.

Namun saat ini belum tersedianya suatu Aplikasi mobile yang dapat meningkatkan minat belajar bagi orang tua, dewasa \& anak, dan juga belum tersedianya media atau Aplikasi mobile yang berbasis edukasi dalam ilmu pengetahuan tentang pengenalan jenis sayur-sayuran yang berbasis Android. Lalu media saat ini yang menyajikan tentang nama-nama sayuran juga masih kaku dan kurang diminati karena juga data-data informasi yang tidak akurat. Dengan dibantu Aplikasi mobile berbasis Android, ilmu pengetahuan dapat dikemas menjadi bentuk yang lebih menarik. Aplikasi ini akan membantu dan memudahkan pengguna dalam mempelajari dan meningkatkan akan ilmu pengetahuan tentang pengenalan jenis sayur-sayuran di Indonesia dan meningkatkan minat akan membaca pada orang tua, orang dewasa dan anak. 
Berdasarkan uraian diatas, maka peneliti akan mengangkat judul "Aplikasi Pengenalan Jenis SayurSayuran Berbasis Android". Aplikasi ini akan dibuat kedalam dua bagian, yaitu bagian pertama adalah pembelajaran yang berisi informasi seputar nama - nama sayuran, yang ada di Indonesia. Dan kedua adalah kuis, dimana nantinya pengguna akan diuji pengetahuannya berdasarkan informasi yang telah diberikan sebelumnya. Tujuan penelitian ini adalah membuat sebuah Aplikasi pengenalan jenis sayur-sayuran yang menarik dengan media smartphone yang dapat meningkatkan minat belajar pada orang tua, orang dewasa dan anak - anak, mengimplementasikan metode pembelajaran yang menarik, efektif dan efisien kepada orang tua, orang dewasa dan anak-anak, membuat sebuah Aplikasi pengenalan jenis sayuran secara digital serta mudah di akses kapan saja, sebagai pijakan dan referensi bagi setiap orang orang tua untuk bahan belajar untuk anak-anak mereka, mempermudah kegiatan setiap orang untuk belajar dan mencari lebih dalam tentang jenis sayuran yang ada di Indonesia. Hasil penelitian ini diharapkan dapat gambaran dan referensi tentang perbandingan proses pengetahuan tentang jenis sayur-sayuran yang ada di Indonesia.

\section{PENELITIAN RELEVAN}

Penelitian pertama adalah penelitian yang dilakukan oleh Siti Annisa furqan, dengan judul Aplikasi Nama Ilmiah Hewan dan Tumbuhan Berbasis Android, Tujuan penelitian Aplikasi ini dapat digunakan untuk mencari nama ilmiah hewan dan tumbuhan, yang telah memiliki wadah atau tempat khusus untuk mempermudah para pengguna perangkat seluler dalam pencarian arti dari nama ilmiah hewan dan tumbuhan,mempermudah proses belajar mengajar bagi para pelajar dan pengajar SMP, terutama dalam pelajaran Ilmu Pengetahuan Alam. Para pengajar dapat dengan mudah memperkenalkan nama ilmiah hewan dan tumbuhan dengan cara menginstal aplikasi nama ilmiah hewan dan tumbuhan ini di perangkat seluler (Furqan, 2015).

Penelitian yang kedua adalah penelitian yang dilakukan oleh Hendika Wiryadan, dengan judul Aplikasi Pengenalan Pohon Menggunakan Qr code Berbasis Android, program studi Ilmu Pengetahuan Alam, kampus Universitas Indraprasta PGRI pada tahun 2017. Tujuan Aplikasi ini dapat digunakan untuk sebagai pengenalan pohon dengan cara cukup memindai kode Qr. Adapun penelitiannya membahas tentang sistem aplikasi edukasi berbasis Qr code menggunakan Android (Wiryadan, 2017).

\section{METODE PENELITIAN}

Metode penelitian adalah salah satu teknik atau cara mencari data, memperoleh, mengumpulkan atau mencantumkan data yang tepat digunakan untuk keperluan dan faktor-faktor yang berhubungan dengan pokok pembahasan sehingga akan dapat suatu kebenaran atas data yang diperoleh. Metode penelitian adalah metode yang digunakan untuk mengetahui hasil dari penelitian dengan cara mengumpulkan, mencatat, dan menganalisis informasi data yang ada. Dengan ini Model Prototyping menjadi pilihan yang digunakan dalam pengembangan:

Model Prototyping (Metode Prototype) merupakan satu metode dalam pengembangan perangkat lunak, metode ini merupakan suatu paradigma baru dalam pembuatan atau pengembangan perangkat lunak. Metode ini adalah evolusi dalam dunia pengembangan atau pembuatan perangkat lunak, metode ini juga merevolusi metode pengembangan atau pembuatan perangkat lunak yang lama, yaitu sistem sekuensial yang biasa dikenal dengan nama Metode Waterfall. "Prototyping juga mendokumentasikan aktivitas sistem informasi meliputi input, pemrosesan, output, penyimpanan dan pengendalian", Menurut (O'Brien, 2015) Dalam metode prototypelprototyping, perangkat lunak yang dihasilkan kemudian dipresentikan kepada klien, dan klien tersebut diberikan kesempatan untuk memberikan masukan dan kritikan, sehingga software yang dihasilkan sesuai dengan kebutuhan dan keinginan pelanggan. Perubahan perangkat lunak dapat dilakukan berkali-kali hingga dicapai kesepakatan bentuk dari software yang akan dikembangkan. 


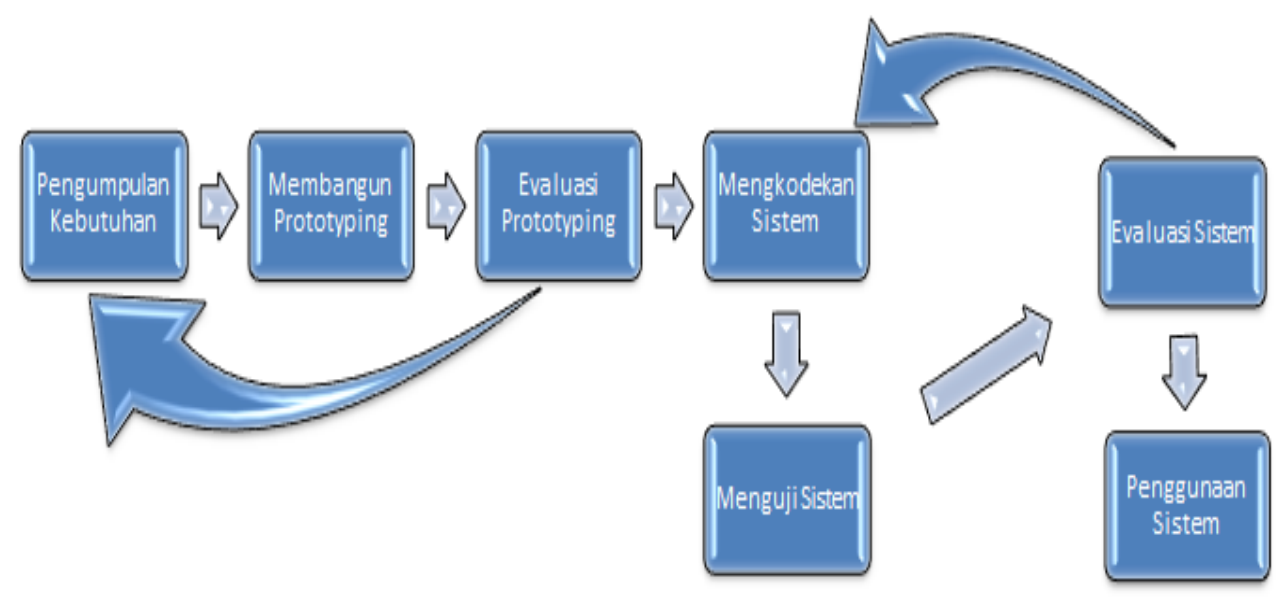

Gambar 1. Tahapan - tahapan Prototyping

\section{HASIL DAN PEMBAHASAN}

Dengan melihat permasalahan yang ada dimasyarakat sekarang ini masih minimnya pengetahuan dalam mempelajari dan mengenal jenis sayur-sayuran yang ada di Indonesia serta banyak diantaranya yang belum pernah menggunakan Aplikasi tentang pengenalan jenis sayur-sayuran. Maka dari itu penulis memperkenalkan salah satu media digital yang dapat digunakan untuk memuat informasi tentang pengenalan jenis sayur-sayuran yaitu media teknologi Android.

Berikut adalah perancangan flowchart dan peseudocode untuk Aplikasi Pengenalan Jenis SayurSayuran Berbasis Android.

\section{Menu Splash Screen}

Flowchart

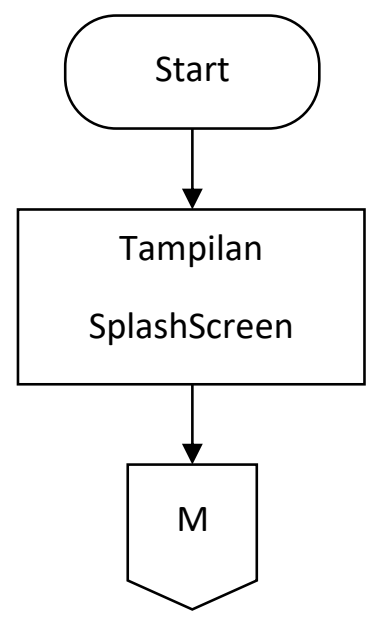

Gambar 2 Flowchart Tampilan Splash Screen 


\section{Menu Utama}

Flowcart Menu Utama

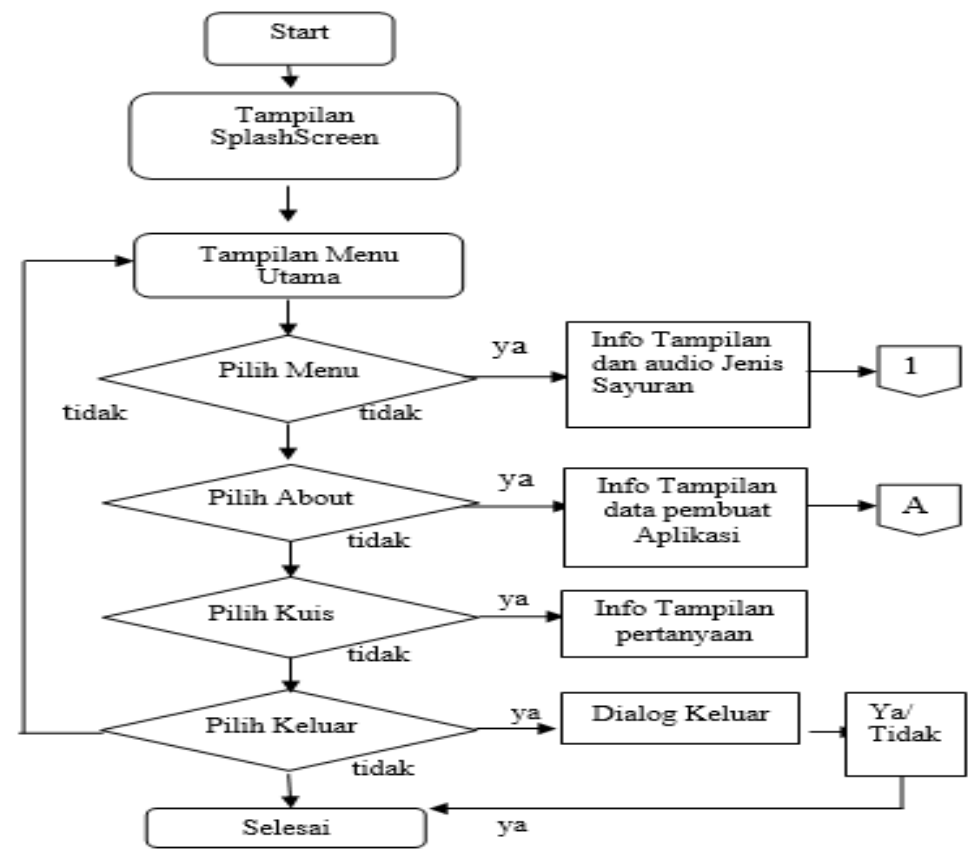

Gambar 3. Flowchart Tampilan Menu Utama

\section{Tampilan Menu Konten}

Flowchart Tampilan Menu Konten

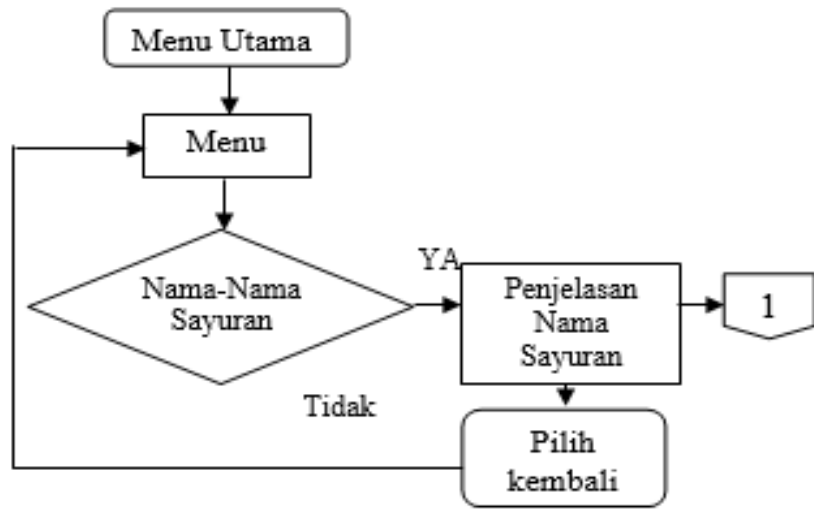

Gambar 4. Flowchart Tampilan Menu Dalam Konten

\section{Menu About}

Flowchart About

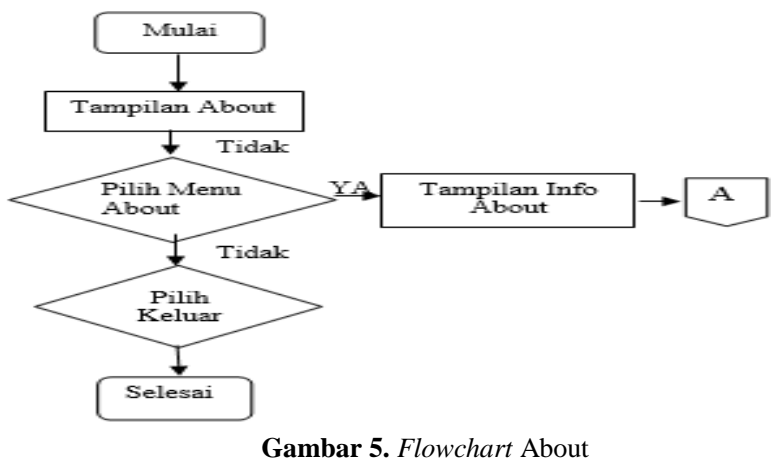




\section{Menu Kuis}

Flowchart Menu Kuis

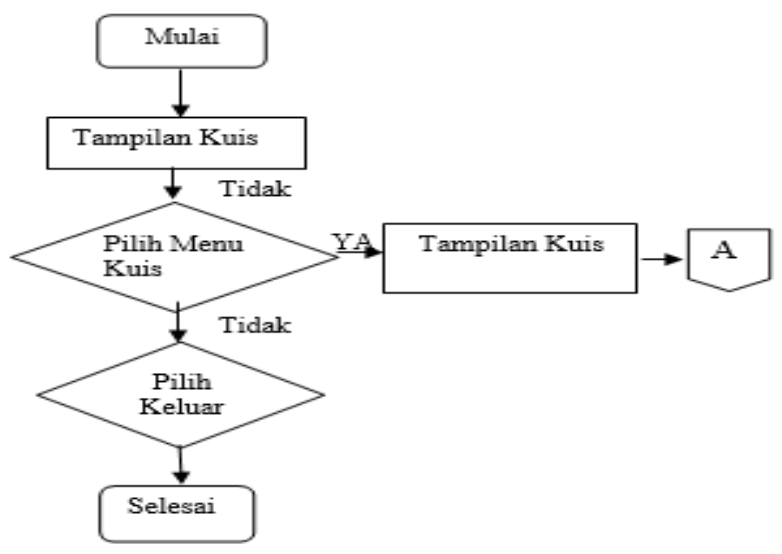

\section{Menu Keluar}

Gambar 6. Flowchart Kuis

Flowchart keluar

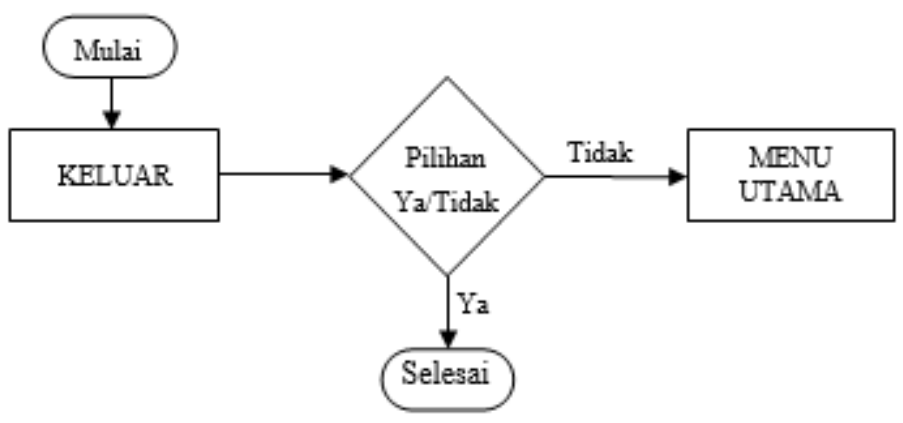

Gambar 7. Flowchart Keluar

Untuk pembuatan Aplikasi jenis sayur-sayuran ini penulis menggunakan Android Virtual Device (AVD) yang ada Android studio dan smartphone berbasis Android. Berikut tampilan hasil uji coba program.

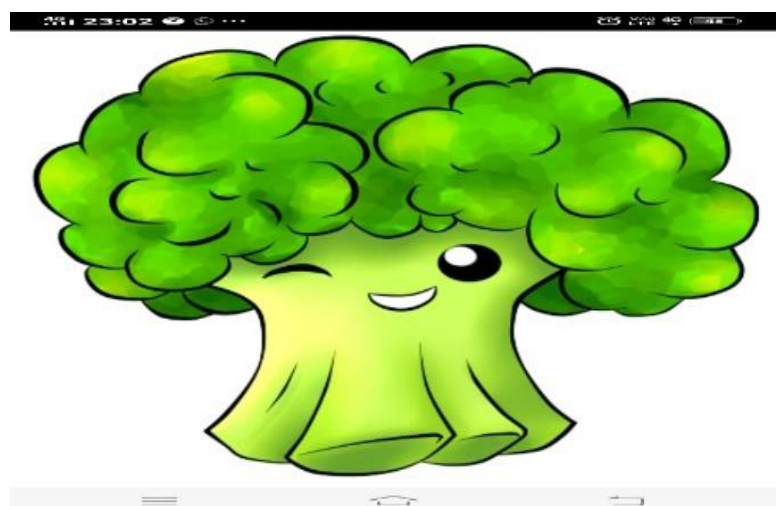

Gambar 8. Tampilan Menu Splash Screen

Tampilan Menu Splash Screen adalah tampilan awal saat aplikasi pertama kali dijalankan 


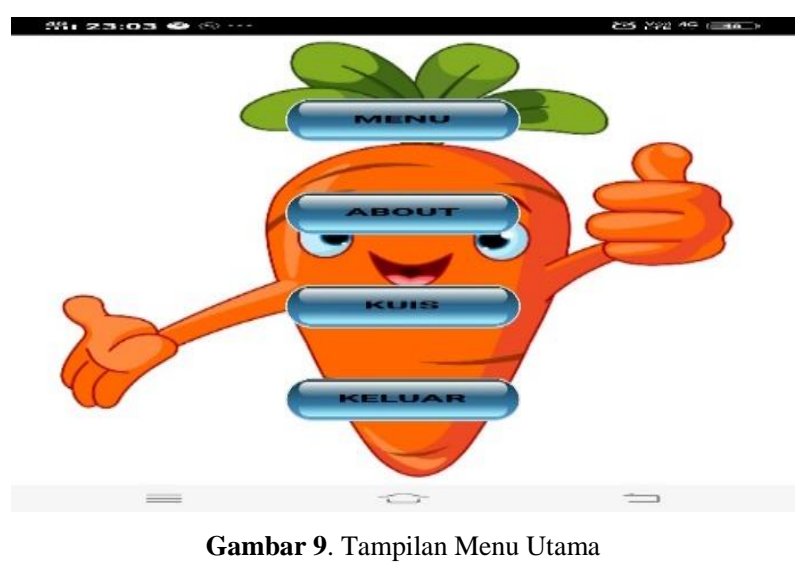

Pada Menu Utama terdapat 4 button untuk mengakses ke menu-menu yang lain seperti Menu, About, Kuis dan Keluar.

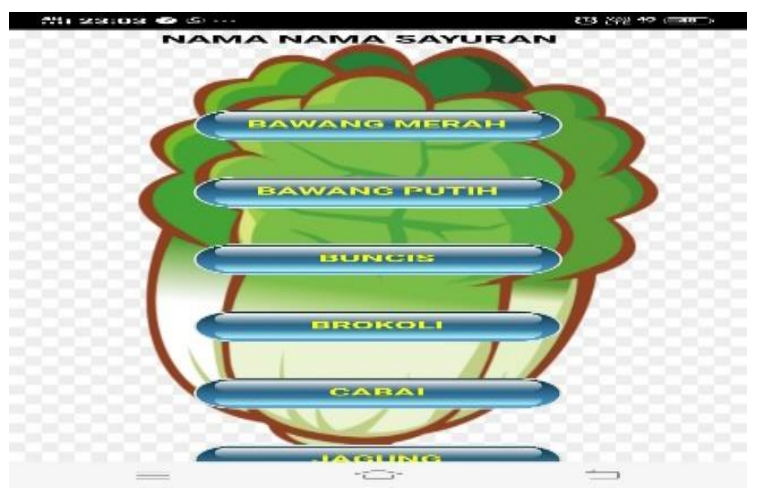

Gambar 10. Tampilan Menu Nama-Nama Sayuran

Pada Tampilan Menu Nama-nama sayuran berisi nama-nama sayuran

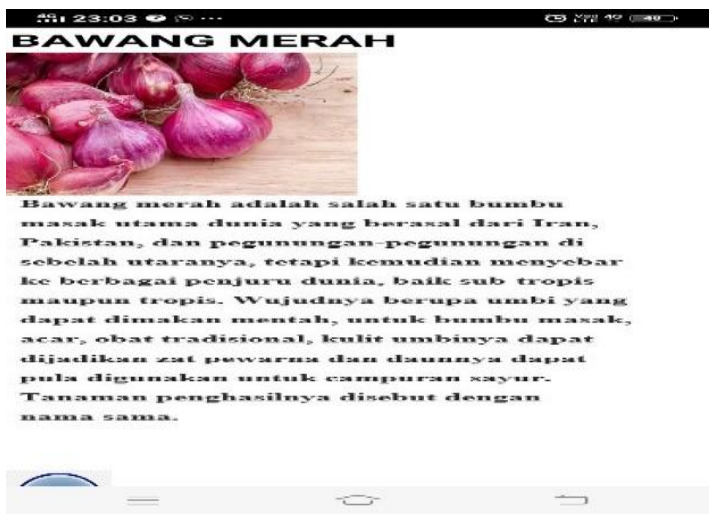

Gambar 11. Tampilan Menu Informasi Sayuran

Pada gambar diatas berisi tentang informasi sayuran seperti asal sayuran, bentuk dan kegunaan. 


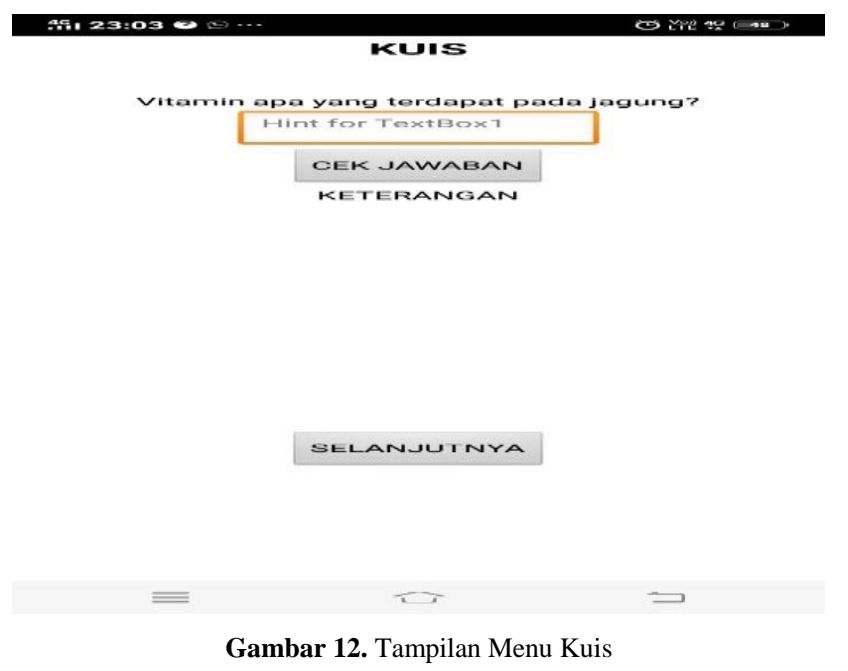

Pada Tampilan Menu Kuis berisi soal-soal yang berhubungan dengan sayuran, serta terdapat button cek jawaban beserta keterangan.

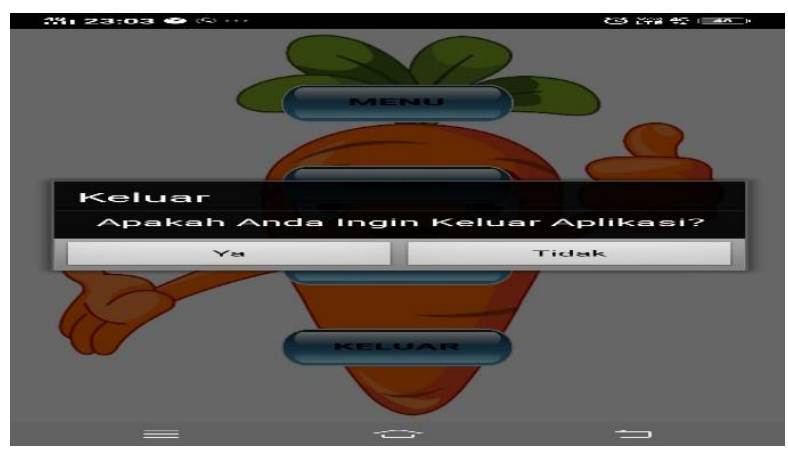

Gambar 13. Tampilan Menu Keluar

Menu keluar adalah menu untuk keluar dari aplikasi pengenalan jenis sayur-sayuran

\section{SIMPULAN}

Berdasarkan hasil perancangan sistem yang penulis lakukan, maka penulis melakukan kesimpulan. Dan mengajukan beberapa saran-saran yang berhubungan dengan pembahasan yang ditemukan dibabbab sebelumnya diantaranya, Aplikasi Pengenalan Jenis Sayur-Sayuran yang ada di Indonesia dapat dipergunakan oleh para pengguna sebagai media alternatif untuk mengetahui sejauh mana pengetahuan mengenai pengenalan sayur-sayuran yang ada di Indonesia kapanpun dan dimanapun melalui Aplikasi berbasis Android, Aplikasi ini memberikan kemudahan kepada guru dan siswa dalam proses pembelajaran. Kelemahan Aplikasi ini karena untuk saat ini hanya dapat dijalankan diplatfrom Android.

\section{DAFTAR PUSTAKA}

Furqan, S. A. (2015). Aplikasi Nama Ilmiah Hewan dan Tumbuhan Berbasis Android. Fakultas Teknik, Matematika dan Ilmu Pengetahuan Alam. Universitas Indraprasta PGRI:Jakarta

Marimin. (2011). Pengertian Aplikasi. edel.staff.unja.ac.id

O’Brien, J. A. (2015). Pengantar Sistem Informasi.

Safaat. (2012). Android pemrograman aplikasi mobile smartphone dan tablet PC berbasis android. Informatika.

Wiryadan,H. (2017). Aplikasi Pengenalan Pohon Menggunakan Qr code Berbasis Android. Fakultas Teknik, Matematika dan Ilmu Pengetahuan Alam. Universitas Indraprasta PGRI 